\title{
JUDICIAL REVIEW OF DECISIONS OF DISCIPLINARY TRIBUNALS OF VOLUNTARY ASSOCIATION: THE POST-1994 INTERPRETATION
}

\author{
Mbuzeni Johnson Mathenjwa \\ BJuris LLB LLM LLD \\ Associate Professor in Law, School of Law \\ University of South Africa (UNISA)
}

\begin{abstract}
SUMMARY
The relationship between a voluntary association and its members is founded on a contract. The constitution of the association regulates the acquisition and termination of the membership of the association. The courts have always had the jurisdiction to hear disputes between members of the association, and they can also interfere with its decision if it has acted ultra vires, or in an instance where its decision was vitiated by bias. After the dawn of the new constitutional democracy, the Constitution became the supreme law of the Republic, and it enshrined the transformative clauses. Thus, the process of transforming the adjudication of disputes in the private sector has to be aligned with the values embedded in the Constitution. This article explains the review of the decisions of a disciplinary tribunal prior to and after the 1994 constitutional dispensation. This it does by discussing the effect of transformative constitutionalism on the review of disputes in the private sector. The relevant transformative clauses in the Constitution are discussed. More particularly, the article concentrates on the effect of the just administrative clause in the Constitution and the Promotion of Just Administrative Act (PAJA) in transforming the rules of natural justice. Furthermore, instances where the PAJA is applicable with regard to the decision of a tribunal of voluntary association, are explained. Finally, a conclusion is drawn on the post-1994 courts' reviews of decisions of disciplinary tribunals of voluntary associations.
\end{abstract}

INTRODUCTION

Voluntary associations, in terms of which people come together for purposes of achieving clearly determined goals, have always been part of our society. Some people associate for religious purposes through institutions such as churches, for sporting purposes in bodies such as soccer teams, karate or rugby teams. The associations are constituted by agreements in the form of contracts among its members. Such an agreement, in every specific case, becomes the constitution of the association. A voluntary association can thus, be defined as an organization formed by members who voluntarily come together to form or join the association. The nature of the relationship established between the voluntary association and its members constitutes 
an agreement in terms of which each member submits contractually to the decisions of the body administering the association on whom they have conferred the right and power to make binding decisions on matters that affect their relationship inter se. ${ }^{1}$ In cases where disputes occur among members of the association, they are resolved in terms of the constitution. This view is reinforced by the judgment of Turner $v$ Jockey Club of South Africa, ${ }^{2}$ where the Court held that the relationship between the voluntary association and its members is contractual, and that that relationship is governed by both the association's rules and regulations which constitute the terms of the contract between the parties, and by the applicable common law. Despite the contractual nature of the relationship between members of the association and its members, however, the courts have exercised jurisdiction and continued to hear disputes among members of voluntary association. Accordingly, this paper will discuss critically, through case analysis, the courts' jurisdiction in and determination of the justifiability of expulsion from membership of a voluntary association, pursuant to the constitutions of such organisations prior to and after the 1994 constitutional dispensation. Prior to 1994, Parliament was supreme and could legislate on any matter. ${ }^{3}$ The adjudication of disputes in the private sphere was limited by the constitutions of these bodies, and the courts could interfere with their decisions only if they had acted ultra vires or the decision had been vitiated by bias. The post-1994 constitutional democracy entrenched the supremacy of the Constitution, enshrined the constitutional values and the Bill of Rights. ${ }^{4}$

Central to the inquiry in this article is the determination of the post-1994 interpretation, where the courts applied transformative constitutionalism in adjudicating disputes involving both the private and public sectors. To contextualize the discussion in this article properly, the transformative clauses of the Constitution, which inform the courts' adjudication of the disputes between members of voluntary associations, is explained. Finally, a conclusion is drawn about the effect of just administrative action, the Promotion of Administrative Justice Act, ${ }^{5}$ and the right of access to court on the adjudication of disputes relating to decisions of disciplinary tribunals of voluntary associations.

\section{JUDICIAL REVIEW OF THE DECISION OF THE DISCIPLINARY TRIBUNAL OF VOLUNTARY ASSOCIATION}

At common law entities were classified either as public or private bodies. An entity would usually be classified as "public" if it had been created by statute,

Khyber Rock Estate East Home Owners Association v 09 of Erf 823 Woodmead Ext 13 CC (7689/2006) [2007] ZAGPHC 137 par 23.

1974 (3) SA 633 (AD).

3 S 30 of the then Republic of South Africa Act 110 of 1983 provided that Parliament was the sovereign legislative authority in and over the Republic.

S 2; 7-35 of the Constitution of the Republic of South Africa, 1996.

3 of 2000 . 
exercised statutory powers, or was funded by public money. ${ }^{6}$ As pointed out above, the relationship between private bodies and their members is based upon voluntary agreements. In order to apply the principles of review of a decision of a voluntary association, the court must deduce what is required from the terms of such agreement.

The rationale for the court to exercise jurisdiction over these matters is articulated by Snyder, who states that, when a person takes up membership of an association, he or she acquires a propriety right in that association which is as much a matter of importance for the court's consideration as that person's claim for possession of any property purchased by him or her. ${ }^{8}$ Baxter argues that these bodies source their powers from contracts and not statutes. Such powers are as coercive as those of public authorities. Since many principles of administrative law are designed to protect individuals from the abuse of power, these principles are applied in identical form to voluntary associations. ${ }^{9}$ De Ville supports this view when he states that the decisions of a voluntary association which were coercive in nature, such as disciplinary proceedings, have always been subjected to administrative law principles.

In the English judgment of Andrews $v$ Mitchell, ${ }^{11}$ the House of Lords considered an appeal, where the respondent was summarily expelled by the committee of a friendly society, contrary to the rules of the society which required it to prefer charges and hold a disciplinary hearing about a member before he could be expelled for misconduct. The appellant contended that the jurisdiction of courts of law to hear the matter was excluded by the provisions of the rules of the society, which provided that every dispute between the society and its members shall be decided in accordance with the rules of the society, and that the decision of the committee of the society shall be binding and conclusive to all parties.

In finding that the jurisdiction of the court could not be excluded by the rules of the association, Lord Davey held that, "although the power to expel a member from the society is necessary for the due administration of the society, it ought always to be exercised in accordance with the conditions imposed by the rules".

The House of Lords unanimously found that the resolution expelling the respondent should be set aside because no charges had been preferred against him as required by the rules. $^{13}$ This judgment shows that the freedom of the voluntary association to regulate its internal affairs may not extend to the power to exclude the jurisdiction of the courts when a dispute occurs amongst members of the association.

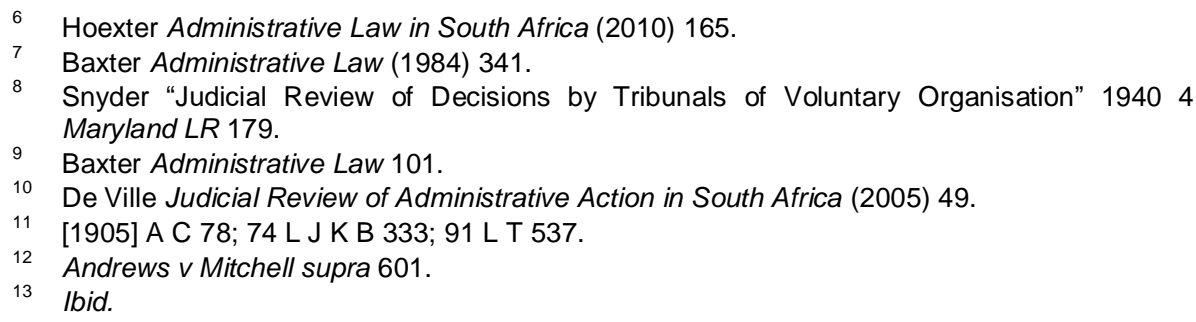


In the South African context this issue prompted the judgment of Crisp v South African Council of Amalgamated Engineers Union. ${ }^{14}$ In considering its jurisdiction to review the decisions of voluntary associations, the Court held that courts will not exercise jurisdiction over the decision of a society, but, if the society acts ultra vires its constitution, the law courts can be appealed to. ${ }^{15}$ If the association acts in accordance with their rules and the dictates of natural justice, however, the courts will not interfere with its decision. ${ }^{16}$

\section{APPLICATION OF THE RULES OF NATURAL JUSTICE}

The decision of the disciplinary tribunal is punitive in nature; hence, the rules of natural justice should apply even where the contract does not make provision for the application of such rules. Devenish et al state that it must be borne in mind that the law on disciplinary matters requires the application of the rules of natural justice, because such proceedings have, by their nature, the potential to influence considerably the rights and interests of the individuals. ${ }^{17}$ Bailey explains the rules of natural justice under English common law as being twofold: firstly, the person affected has the right to prior notice and the right to make representation before a decision is made; and, secondly, the person affected has the right to an unbiased tribunal in the sense that there is no real possibility that the decision-maker might be biased. ${ }^{18}$ Baxter elucidates the meaning of the rules of natural justice or procedural fairness under South African law by stating that it entails that one should hear the other side, that no one should be the judge in his own cause and that the decision-maker should be free of bias. ${ }^{19}$ The purpose of the rules is to ensure that jurisdictional facts and relevant circumstances have been accurately assessed and are designed to promote the correct and fair resolution of disputes. ${ }^{20}$

In the judgment of Jockey Club of South Africa, ${ }^{21}$ the applicant, a jockey, was found guilty of misconduct, and suspended for 20 years from participating in the race club by the domestic tribunal of the jockey club of South Africa. The applicant applied for a court order setting aside his conviction and sentence, based on the grounds that he had not been afforded a fair and impartial hearing by that body, in neglect of the fundamental principles of justice. One of the issues contested by the applicant was the rules of the respondent which allowed a steward to function both as a witness and as a judge. The Court held that, while the rules of natural justice do not require a disciplinary tribunal of a voluntary

1930 AD 255.

Crisp v South African Council of Amalgamated Engineers Union supra 236.

Crisp v South African Council of Amalgamated Engineers Union supra 237.

Devenish, Govender and Hulme Administrative Law and Justice in South Africa (2001) 302.

8 Bailey "Grounds for Judicial Review: Due Process, Natural Justice and Fairness" in Feldman (ed) English Public Law (2009) 668.

19 Baxter "Fairness and Natural Justice in English and South African Law" 197996 SALJ 608.

20 Baxter 1979 SALJ 635

21 Turner $v$ Jockey Club of South Africa supra 633. 
association to follow the procedure and to apply the rules of evidence observed in court of law, the tribunal is still required "to adopt a procedure which would afford the person charged a proper hearing by the tribunal, and an opportunity of producing his evidence, and of correcting or contradicting any prejudicial statement or allegation made against him".22 In setting aside the finding of guilty and the sentence passed on the appellant, the Court held that the finding of the stipendiary stewards was vitiated by the disregard of the requirements of natural justice. ${ }^{23}$

It should be recognized that the contract of the association could be formulated by a lay person or a group of persons not well-versed in the law or even vested with powers that source their gravitas from common law or natural justice; hence, the disciplinary procedure is not expected to adhere to legal procedures as applied in a court of law. It suffices that these bodies give an affected person the opportunity to state his or her case and that the tribunal is not biased.

In Lunt $v$ University of Cape Town, ${ }^{24}$ the Court was called upon to review a decision of the University of Cape Town to refuse to re-register the applicant who had been excluded for the 1988 academic year. It was common cause that the applicant was not given a hearing and that the University had not advised him of the reason for his academic exclusion. In finding that the applicant should have been afforded the opportunity to be heard, the Court held that the existence of a contract should not detract from the applicability of the rules of natural justice in what is essentially a punitive action, taken by the disciplinary officer. ${ }^{25}$

In the pre-1994 dispensation the Court insisted that the rules of natural justice should be applied in the disciplinary hearings of voluntary associations. Despite the application of the rules of natural justice in disciplinary matters, however, the rights of the individuals were not adequately protected because there was no Bill of Rights; Parliament was supreme and could legislate on anything that trampled on individual rights. This view is reinforced by Burns who points out that the doctrine of the rule of law did not play a significant role in protecting human rights during the apartheid era because of the proliferation of legislation which infringed human rights. ${ }^{26}$

\section{THE POST-1994 INTERPRETATION}

With the dawn of the new democratic dispensation in 1994, the Constitution became the supreme law in the Republic, and any law or conduct inconsistent with its provisions was of no force and effect. ${ }^{27}$ The interim

\footnotetext{
Turner v Jockey Club of South Africa supra 646.

Turner $v$ Jockey Club of South Africa supra 659.

1989 (2) SA 438 (C).

Lunt v University of Cape Town supra 448.

Burns Administrative Law (2013) 101.

S 4 of the Constitution of the Republic of South Africa Act 200 of 1993 (the interim Constitution).
} 
Constitution entrenched the Bill of Rights which protected individual rights. ${ }^{28}$ The 1996 Constitution further proclaims the supremacy of the Constitution ${ }^{29}$ and enshrines the Bill of Rights. ${ }^{30}$ Accordingly, the interim Constitution was, and later the 1996 Constitution is, a breakaway from the previous dispensation. In interpreting the law, therefore, courts should display transformative adjudication which requires them to be guided by values inherent in the Constitution when adjudicating legal disputes.

\section{The effect of transformative constitutionalism}

While many constitutions address the relationship between the state and individuals, the South African Constitution is further concerned with the eradication of inequality and imbalances in the private sector. In explaining the purpose of the Constitution, Liebenberg ${ }^{3}$ states that, unlike many constitutions, the primary concern of the Constitution is not to constrain state power but to facilitate a change in unjust political and social relations in South Africa. This view is supported by Klare who argues that the Constitution intends to irradiate democratic norms and values into the socalled private sphere. ${ }^{32}$ In this regard the Constitution of South Africa is transformative. Klare defines "transformative constitutionalism" as a longterm project of constitutional enactment, interpretation and enforcement committed to transforming a country's political and social institutions and power relationships in a democratic, participatory and egalitarian direction. ${ }^{33}$ Moseneke argues that, although the premise of social justice does not surface in the founding provisions or in the Bill of Rights, a creative jurisprudence of equality, coupled with a substantive interpretation of the content of socio-economic rights, should restore social justice as the premier foundational value of our constitutional democracy. ${ }^{34}$ Pieterse argues that South African constitutionalism attempts to transform the society from one which was deeply divided by the legacy of apartheid into one based on democracy, social justice, equality, dignity and freedom. ${ }^{35}$

In transforming the society, the Constitution does not only regulate the relationship between the state and individuals, but it also transforms the private sector in line with its underlying values. There are various clauses of the Constitution which support this view that the private sector should comply with its values when conducting its business. For instance, Hoexter points out that the possible explanation for the reviewability of private power post-1994 lies in section 8(2) of the Constitution, which contemplates the

S 7-35 of the interim Constitution.

$\mathrm{S} 2$ of the Constitution.

S 7-35 of the Constitution.

Liebenberg "Needs, Rights and Transformation: Adjudicating Social Rights" 200617 Stell LR 6.

Klare "Legal Culture and Transformative Constitutionalism" 199814 SAJHR 155.

33 Klare 1998 SAJHR 150.

34 Moseneke "The Fourth Bram Fischer Memorial Lecturer: Transformative Adjudication" 2002 18 SAJHR 314.

35 Pieterse "What Do We Mean When We Talk About Transformative Constitutionalism?" 2005 20 SA Public Law 158. 
direct horizontal application of the constitutional rights in the private sphere. ${ }^{36}$ This view is reinforced by Pieterse who argues that: ${ }^{37}$

The extension of the constitutional transformative project to the so-called "private sphere" is affirmed by section 8(2) and (3) of the Constitution which acknowledge that rights may in appropriate circumstances apply also to private parties, hence allowing for constitutional standards to infiltrate private relationships.

Hoexter further states that the application of the Bill of Rights to the private sphere could possibly be sourced from section 33 of the Constitution, which guarantees everyone the right to just administrative action, although this right is tied to the use of public power rather than private power. ${ }^{38}$

\section{The right to just administrative action}

Prior to the new constitutional democracy, the review of administrative action was not sourced from either the Constitution or legislation. ${ }^{39}$ In common law, the superior courts exercised inherent jurisdiction to review administrative action, but the powers of the courts were often restricted or ousted by Parliament, and so Hoexter points out that, although the supreme courts could review the lawfulness of administrative actions, Parliament had the power to determine what was unlawful or not unlawful. ${ }^{40}$ This was due to the constitutional system of parliamentary sovereignty that prevailed in the period prior to the 1994 constitutional dispensation, which constrained the common-law review power of the supreme courts. The entrenchment of administrative-law principles in the Bill of rights was, thus, aimed at removing the abuse of the wide discretionary powers of Government. ${ }^{41}$ The 1996 Constitution provides that: "Everyone has the right to administrative action that is lawful, reasonable and procedurally fair". ${ }^{2}$ Furthermore, everyone whose right has been adversely affected by administrative action is guaranteed the right to be given written reasons. ${ }^{43}$ The power of judicial review after 1994 is no longer sourced from the common law inherent powers of the superior courts, but is sourced directly from the Constitution. In reinforcing this view, Hoexter argues that, before 1994, the review power of the courts was no longer grounded in the common law, and that the

36 Hoexter Administrative Law in South Africa (2007) 121.

37 Pieterse 2005 SA Public Law 162. S 8(2) of the Constitution provides that: "A provision of the Bill of Rights binds a natural or juristic person if, and to the extent that, it is applicable, taking into account the nature of the right and the nature of any duty imposed by the right. $S$ 8(3) provides that, when applying provision of the Bill of Rights to a natural or juristic person in terms of ss (2) a Court, in order to give effect to a right in the Bill must apply, or if necessary develop, the common law to the extent that legislation does not give effect to the right; and may develop rules of the common law to limit the right, provided that the limitation is in accordance with s 36(1)".

38 Hoexter Administrative Law in South Africa (2007) 121.

39 De Ville Judicial Review of Administrative Action in South Africa 1.

40 Hoexter "Just Administrative Action" in Currie and De Waal (eds) The Bill of Rights Handbook (2013) 645.

41 Hoexter in Currie and De Waal (eds) The Bill of Rights Handbook 644-645.

42 S 33(1) of the Constitution.

43 S 33(2) of the Constitution. 
doctrine of constitutional supremacy prevented the legislature from infringing the right to administrative justice.

The Constitution required Parliament to adopt legislation to give effect to the right to a just administrative action. ${ }^{45}$ Consequently, Parliament adopted the Promotion of Administrative Justice Act (PAJA). ${ }^{46}$ PAJA defines "administrative action" as meaning: ${ }^{47}$

any decision taken, or any failure to take a decision by -

(a) an organ of state when -

(i) exercising a power in terms of the Constitution, or a provincial constitution or,

(ii) exercising a public power or performing a public function in terms of any legislation, or

(b) a natural or juristic person, other than an organ of State, when exercising a public power or performing a public function in terms of an empowering provision which adversely affects the rights of any person and which has a direct, external legal effect.

The definition of the Act entails that, for a conduct to qualify as administrative action, it must have been taken by an organ of State exercising a power in terms of the Constitution or legislation. ${ }^{48}$ The conduct of a juristic or natural person may qualify as administrative action only if such conduct is performed in the exercise of powers in terms of the Constitution or legislation. To qualify as administrative action, the conduct of a juristic or natural person must have adversely affected the rights of a person. ${ }^{49}$ Furthermore, the conduct of both the organ of State and juristic or natural person may qualify as administrative action if these institutions exercise public power, or perform a public function in terms of the Statute.

The formulation of the Act shows that not all conducts the actions of a public body qualify as administrative action, and also that private bodies may exercise public powers. A practical case of a public body performing a private function is seen in the case of Cape Metropolitan Council $v$ Metro Inspection Services (Western Cape) $C C^{50}$ In this case, the Metropolitan Council - the appellant, an organ of state acting in terms of the legislation awarded a tender to the respondent, and later cancelled the tender owing to a breach of the terms of the contract by the respondent. The court held that, while the appellant derived its power to enter into the contract with the respondent from the statute, it derived its power to cancel the contract from

\footnotetext{
Hoexter in Currie and De Waal (eds) The Bill of Rights Handbook 646.

S 33(3) of the Constitution.

3 of 2000 .

$S 1$ of PAJA.

48 De Ville Judicial Review of Administrative Action in South Africa 41. An organ of state is defined in s 239 of the Constitution as meaning any department of state or administration in the national, provincial and local sphere of government; or any other functionary or institution exercising a power or performing a function in terms of the Constitution or provincial constitution; or exercising a public power or performing a public function in terms of any legislation, but it does not include a court or judicial officer.

49 De Ville Judicial Review of Administrative Action in South Africa 51.

502001 (3) SA 1013 (SCA).
} 
the terms of the contract and the common law. ${ }^{51}$ Consequently, it was found that the cancellation of the contract did not constitute administrative action entitling the respondent to procedural fairness and reasons in terms of the just administrative-action clause. ${ }^{52}$

While the nature of the conduct and source of the power are determinants of whether the conduct is administrative action or not, the classification of the conduct of private bodies that are not regulated by statutes as public powers is not without difficulty. This view is reinforced by Hoexter who argues that, although the formulation seems to exclude entirely the conduct of private bodies, such as the exercise of disciplinary action by churches, there is room for the argument that some regulatory bodies are actually exercising a public function. ${ }^{53}$

In Van Zyl v New National Party, ${ }^{54}$ the applicant was the representative of the New National Party (NNP) in the legislature of the Western Cape. The NNP instituted disciplinary proceedings against the applicant for misconduct, and it subsequently recalled her from the provincial legislature. In deciding whether the recalling of the applicant was the exercise of public power, the Court held that, on the basis of the meanings of the constituent components of the concept "exercising a public power", it conveys the ability to act in a manner that affects or concerns the public. ${ }^{55}$ The Court found that the exercising of the authority to recall a permanent delegate to the NCOP in terms of the Constitution constitutes the exercise of public power. ${ }^{56}$

This case reflects a situation where the political party was enabled by the Constitution to recall its member who was a permanent delegate to the NCOP. ${ }^{57}$ The affected member was performing a public function as a representative of a political party at the NCOP. The recalling of the member affected the community and, by that very fact, it is a public function. Since the exercise of the power to recall the party member is authorized by the Constitution, the political party was exercising public power in terms of the enabling Act.

In the judgment of Max $v$ Independent Democrats, ${ }^{58}$ the applicant, a member of the Independent Democrats (the respondent), was found guilty by the respondent's disciplinary tribunal of misconduct and expelled from the party.

The applicant contended that the provisions of PAJA or, alternatively, the common-law rules of administrative law are applicable in these disciplinary proceedings. The Court avoided a finding as to whether PAJA or common

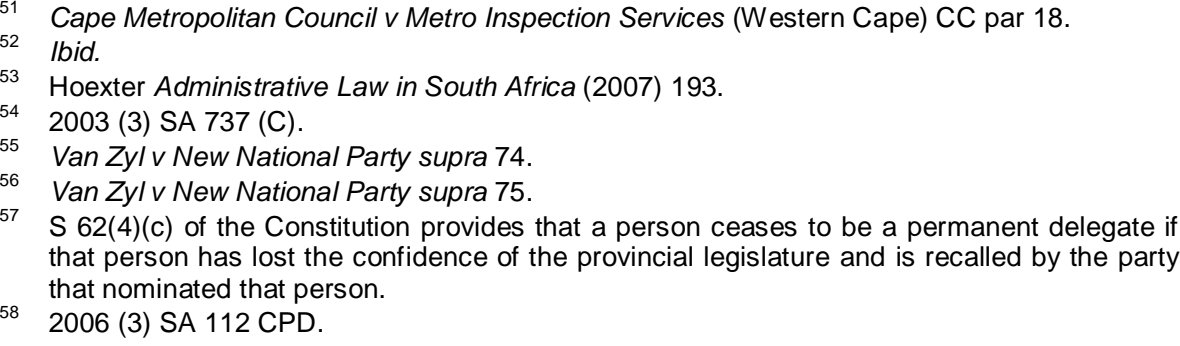


law was applicable, but it emphasized that the respondent exercised powers that should adhere to the rational principles which are the requirements of public law. ${ }^{59}$ This entails that the rights to procedural fairness and the body of administrative law were applicable to the disciplinary process instituted against the applicant. ${ }^{60}$

Accordingly, the classification of the respondent's act as a public function entails that the action should be congruent with the Constitution which enshrines a foundational principle of accountability and fairness.

The question of whether the public at large has an interest in such a decision has an impact on determining the nature of the conduct of a private person. The Court applied this test in the case of Louisvale Pirates $v$ South African Football Association. ${ }^{61}$ In considering whether the decision of the disciplinary tribunal of the South African Football Association (SAFA) in withdrawing a team of soccer players from SAFA, was the exercise of a public function, it was held that, although SAFA was a voluntary association, the public at large has an interest in what happens in soccer generally. ${ }^{62}$ Consequently, the Court found that the disciplinary procedure and hearing by SAFA constituted the exercise by SAFA of a public function. ${ }^{63}$ Given the huge interest that the public has in soccer, as evidenced by the public investment in the sport by paying for travelling and watching soccer at the soccer stadiums, any decision of SAFA regarding the sport may affect the public accordingly.

\section{The right of access to Courts}

The Republic of South Africa is founded, amongst other things, on the value of the supremacy of the Constitution and the rule of law. The rule of law entails that everyone is equal before the law; public power is exercised in terms of the authority conferred by law, and courts are responsible for enforcing the law, including the common law and statute, in a manner that protects the basic rights of all. ${ }^{64}$ Access to courts is, thus, pivotal for the preservation of the rule of law. The Constitution guarantees everyone "the right to have any dispute that can be resolved by the application of law decided in a fair public hearing before a court or, where appropriate, another independent and impartial tribunal or forum" ${ }^{65}$ According to Currie and De Waal, the significance of the right of access to courts is that it outlaws the post-1994 law practice of ousting the jurisdiction of the courts from enquiring into the legal validity of certain conduct. ${ }^{66}$ This view is reinforced by Loots who states that legislation which inhibits the judicial resolution of a dispute, or which constitutes an impediment to a person's constitutional right to have

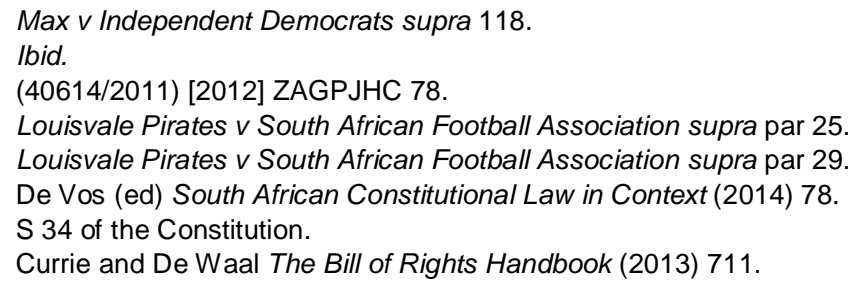


disputes resolved may be challenged in terms of the provision of the right of access to courts. ${ }^{67}$

The effect of the provisions of the Constitution on the reviewability of the decisions of voluntary associations is that tribunals, other than the courts hearing the disputes, are required to be independent and impartial when they are involved in the resolution of legal disputes. ${ }^{68}$

It seems that the supremacy clause of the Constitution is broad and influences any conduct of the private sector which is inconsistent with the Constitution. In this regard, the judicial review of the decision of disciplinary proceedings of voluntary association is no longer the same as it was before 1994, where courts would not interfere with the contractual arrangements of the parties even though such contracts offended individual rights, since these rights were not enshrined in the Constitution. In supporting the arguments for transforming the court's adjudication of private disputes, Pieterse argues that it is the private sphere where oppression of all kinds is often found and the effect of vulnerability at its most concrete is experienced. ${ }^{69}$ Accordingly, parties in a voluntary association cannot discriminate in their disciplinary proceedings without offending the nondiscriminatory clause of the Constitution. ${ }^{70}$ Such discriminatory conduct would be inconsistent, not only with the Bill of Rights, but also with the founding values of the Constitution which include, among other things, human dignity, non-racialism and non-sexism. ${ }^{71}$

\section{APPLICATION OF JUST ADMINISTRATIVE ACTION TO PRIVATE BODIES}

As pointed out above, section 33 of the Constitution, which guarantees everyone the right to an administrative action that is lawful, reasonable and procedurally fair, is one of the transformative clauses of the Constitution. This provision seems to be targeting public bodies since its application is limited to administrative action.

The question of the application of PAJA to a decision of the disciplinary tribunal of an association was prompted in the Marais $v$ Democratic Alliance. ${ }^{72}$ In answering the question of whether the decisions of a voluntary association can qualify as administrative action, the Court held that it is clear

67 Loots "Access to the Courts and Justiciability" in Woolam et al Constitutional Law of South Africa (2006) 81.

68 Currie and De Waal The Bill of Rights Handbook point out that s 34 guarantees three distinctive rights for a person involved in a legal dispute; first it creates a right of access to a court; second, it requires tribunals other than courts to be independent and impartial when they are involved in resolution of legal disputes, and thirdly it is a due-process guarantee, requiring the legal disputes to which it applies to be decided in a fair and public hearing. Pieterse 2005 SA Public Law 160.

$S 9(4)$ of the Constitution.

$71 \mathrm{~S} 1$ of the Constitution provides that the Republic of South Africa is a democratic state founded on the values, among others, of human dignity, the achievement of equality and the advancement of human rights and freedoms, non-racialism and non-sexism.

722002 (2) BCLR 171 (C). 
from the definition of "administrative action" as it appears in section 1 of PAJA, that a decision of a voluntary organization, such as the Democratic Alliance, qualifies as such only under restricted circumstances. The decision must, in the first place, constitute the exercise of public power or the performance of a public function and, in the second place, be exercised in terms of an empowering provision. ${ }^{73}$ The Court further held that the rules of natural justice and procedural fairness are encapsulated in section 33(1) of the Constitution. ${ }^{74}$

Since many disciplinary tribunals of voluntary associations do not exercise public power, but their powers arise from contract, it seems that their actions may not be covered by the just administrative clause of the Constitution. The court statement that the rules of natural justice are encapsulated in section 33(1) of the Constitution, however, entails that these rules, as they were understood prior to the 1994 democratic dispensation, have been transformed by the new Constitution. In this regard, the transformative effect of the rules encapsulates the private sector.

It is stated above that the fairness of the disciplinary proceedings was satisfied under the common-law notion of natural justice, when the person was given an opportunity to state his or her case and the process was free of bias. ${ }^{75}$ In terms of the Constitution, however, every person whose right is affected by any administrative action has the right to be given reasons. ${ }^{76}$ This provision affects the private sphere in that the disciplinary tribunals of private bodies should be required under the new constitutional dispensation to give reasons for their decisions.

The failure of the disciplinary tribunal of a voluntary association to give reasons for its decision arose in the case of Ngiba $v$ African Peoples Convention. ${ }^{77}$ The applicants were councillors of the eThekwini Municipality, representing the African Peoples Convention (APC) which was the respondent. The issue arose from the decision of the respondent to recall the applicants as APC councillors. The applicants declined to resign. Subsequently, charges were brought against them and disciplinary proceedings instituted against them. The applicants were found guilty and removed as councillors. They were not given reasons for the decision. They appealed to the internal appeal process of the respondent and, furthermore, approached the Court for an interim interdict, preventing the respondent from removing them as councillors, pending the outcome of internal appeal process.

In interpreting the constitution of the respondent which allowed for the sanction to be enforced, pending an internal appeal process, the Court held that, where the matter involves public representation, the issue is not one which is simply contractual and that, where the suspension of the ruling, pending an appeal, is excluded, the Court would still be empowered to grant

\footnotetext{
Marais v Democratic Alliance supra 48.

Marais v Democratic Alliance supra 67.

Turner v Jockey Club of South Africa supra 633.

S 33(2) of the Constitution.

(8552/2012, 84 57/2012) [2013] ZAKZDHC 21.
} 
relief. ${ }^{78}$ The Court ordered that the respondent furnish the applicants with reasons for the decision within 10 days, and that, pending the finalization of the appeal procedure instituted by the applicants, their membership be reinstated with immediate effect. ${ }^{79}$ This case reinforces the view that, under the 1996 Constitution, the disciplinary tribunals of private bodies are required to give reasons for the decisions which affect their members.

Case law demonstrates that the body of administrative law, envisaged by the court, should be informed by the Constitution in that some of the provisions of the Constitution are transformative of the administrative law, whereas accountability and openness are constitutional values which both the public and private sectors are required to uphold when doing their business. ${ }^{80}$

\section{CONCLUSION}

At common law the superior courts have jurisdiction to review decisions of the disciplinary tribunals of voluntary associations. The importance of the propriety rights acquired by members when joining the association, and the coerciveness of the decisions of disciplinary tribunals of voluntary associations, necessitated the jurisdiction of the courts to review and protect individual rights from the abuse of power. Owing to the coerciveness of the decisions of disciplinary tribunals, courts exercised jurisdiction even when such jurisdiction was excluded by the constitution of the association. Furthermore, even when the rules of natural justice were excluded by the constitution of the association, courts would still apply these rules when reviewing decisions of the disciplinary tribunals of associations. It should be noted that the protection afforded by the courts to individuals in matters of this nature was not solid and comprehensive owing to the doctrine of parliamentary sovereignty that existed in the pre-1994 dispensation. This system enabled Parliament to outlaw the judgments of courts as it wished.

The dawning of the new democratic dispensation in 1994 replaced the doctrine of parliamentary sovereignty with the supremacy of the Constitution. The entrenchment of the values in the Constitution and the protection of individual rights have had an effect on the courts' adjudication of decisions of disciplinary tribunals of voluntary associations. Owing to the transformative nature of the Constitution, the adjudication of both the public and private sector is transformed, and is informed by the supremacy of the Constitution. In conducting their disciplinary hearings, thus, the tribunals are obligated to comply with the provisions of the Bill of Rights and clauses of the Constitution. The right of access to court does not only entrench the common-law powers of the superior courts to review decisions of voluntary associations, but also requires the tribunal itself to be independent and impartial. The independence and impartiality of the tribunals of voluntary associations could be challenged on the basis of this provision of the

Ngiba v African People's Convention supra 40.

Ngiba v African People's Convention supra 47.

$\mathrm{S} 1$ (b) of the Constitution provides that South Africa is founded on the values that ensure accountability, responsiveness and openness. 
Constitution. Consequently, the clause referring to the right of access to court has the effect of transforming disciplinary tribunals in the private sector which cannot overlook the prescriptions of the Constitution in conducting their business. Furthermore, the entrenchment of the just administrative act in the Constitution entails that the private-sector disciplinary tribunal, exercising public power or performing a public function, is required to apply the just-administrative clause. Given the nature of voluntary associations, such as political parties who are private bodies operating in public sphere, PAJA caches most activities of these private bodies. This is the case because membership of the assembly and a municipal council is linked to the members' membership of a political party. For example, a councillor elected from a political party list vacates office if that councillor ceases to be a member of the relevant political party. ${ }^{81}$ In this scenario, the councillor will be disciplined in terms of the political party's constitution, which must be applied with the provision of PAJA in mind because the termination of the councillor's membership will determine his or her membership of the municipal council. The Courts have applied PAJA in instances where the private body is not exercising powers in terms of any empowering legislation. Although the court decision in the SAFA case is welcomed in extending the application of PAJA to instances where the conduct of a private body is not based on any empowering legislation but on the public interest, the determination of a public function remains a challenge. This gives the courts broader discretion with regard to the determination of public function. A conclusion can be drawn that, although the disciplinary tribunals of voluntary associations are regulated by their constitutions, the court's adjudication of the decisions of these bodies is considerably transformed by the operation of the Constitution.

81 S 27(c) of the Local Government: Municipal Structures Act 117 of 1998. 